\title{
Portrayal of Yorùbá Socio-cultural Heritage in the Practice of the Kegite Movement in Nigerian Tertiary Institutions
}

\author{
Hezekiah Olufemi Adeosun \\ University of Ilorin, Ilorin, Nigeria. \\ hezekiah@unilorin.edu.ng; hezekiahadeosun@yahoo.com
}

\begin{abstract}
This essay examines some aspects of the Yorùbá socio-cultural heritage portrayed in the practice of the Kegite Movement in Nigerian tertiary institutions. The Kegite is one of the student organizations in institutions of higher learning in Nigeria. Membership of the organization is open to only those who support the promotion and culture of palmwine drinking. Participant observation method of data collection which involved the researcher himself in the research setting was adopted. The paper relies on the socio-cultural theory for its analysis. Among the findings revealed in the study are that the Kegite Movement promotes aspects of the Yorùbá heritage which involved entrenching associations, teaching and enhancing morals through songs, method of selecting a king and his chiefs, use of language, and use of palmwine for entertainment purpose. This paper concludes that the Kegite Movement has been a virile organization towards the promotion of the Yorùbá socio-cultural heritage and in uniting the youth in Nigerian tertiary Institutions.
\end{abstract}

\section{Introduction}

Girigiri (2006) defines heritage as a socio-historical concept. He says "heritage is the embodiment of a people's culture, their distinctive inventions for adaptation to the physical environment and for social order. It consists of material and non-material culture that constitute the characteristics and the identity of specific people" (14). A people's heritage manifests in every facet 
of their life: politics, religion, economy, family, institutions, technology, and health care, etc.

Culture, according to Anele (2006:140), is usually imbued with tradition in the sense that, culture is transmitted from ancestors or past ages, and this makes for continuity in a people's life. Thus, culture becomes traditional in the sense that aspects of it that still serve useful purposes are transmitted to future generations. However, from the perspective of a majority of social scientists, culture means much more than just some aspects of human social existence. It is an embodiment of the totality of human existence. As defined by Sanderson (1988), "culture is the total characteristic ways of life of the members of a society which include tools, knowledge and patterned ways of thinking and acting that are learned and shared and are not the direct product of biological inheritance" (112). Elaborating on this definition, Sanderson points out that culture is a complex totality consisting of three interrelated sets of phenomena namely: the tools and techniques or simply the technologies that people have invented to adapt to their environments; the patterns of behavior which individuals engage in as members of society; and the shared beliefs, values and rules that humans create as a means defining their relationships to each other and to their natural environments. Culture has two basic components, which are material and non-material culture. Material culture consists of all the artifacts (the material products) of a society. These include the tools fashioned by man, the products made with these tools for the comfort of man, such as shelter, clothing and weapons. Non-material culture consists of the ideas behind the making or transformation of material object for man's use. These include the norms, values, the belief system, social institution and so on (Atemie \& Girigiri, 2006:1-2).Atemie \& Girigiri, (2006) note that culture has some basic elements which include; customs, norms, values, rite of passage, folkways, mores, and cultural relativism.

Customs are established socially accepted practices. They are often individualised procedures for the establishment of societal cohesion. Norms are the standards that should govern people's behaviour in the roles they occupy. They are the societal expectations of what is 'normal' and therefore, good conducts. Norms are in other words, standards or yardsticks that contain some degree of morality (2-3).

They regulate human behavior and are, therefore, standard for actions. Values have been defined as "conceptions, explicit or implicit, distinctive of an individual or characteristic of a group, of the desirable, which influence the selection from available modes, means and end of an action" (Peil, 1977:23). Rites of passage are ritual activities which usually symbolize that an 
individual has achieved a particular status in the society. Folkways are the etiquette and customs of a people that are not of critical importance to the society. They are important in establishing order and predictability in many lesser matters of life. Mores are rules of behavior that are very important to the society and whose violation would endanger its basic stability (Thomas \& Anderson, 1977:56). Cultural relativism, according to Atemie \& Girigiri (2006), is a doctrine which holds that "no culture is inherently superior or inferior to others, but that, since every culture constitutes an adaptive solution to fundamental human problems, all culture are equally valid" (6). Cultural relativists believe that the standards of one culture need not be used to judge another. The standards for the evaluation of culture can only be from the perspective of the culture under examination and not those of other cultures. Thus, this study focuses on the aspects of the Yorùbá socio-cultural heritage as exemplified in the practice of the Kegite movement in Nigerian tertiary institutions. The next section of this study discusses the Yorùbá people and their origin.

\section{Associations among the Yorùbá}

In the traditional Yorùbá society, men and women frequently formed associations called egbe that provided social and economic support to their members. These organizations furnished an outlet for the Yorùbá love of sociability, eagerness to gain group identities, and pleasure in wearing fine clothing on special occasions. In western and central areas, egbé were part of life during the nineteenth century, and they maintained their vibrancy and public visibility right through the colonial period (Mcintosh, 2010:210). Fadipe (1970) stresses that, "the tendency to form associations and corporations is very strong among the Yorùbá. They are formed for the purpose of promoting and protecting common interests in the fields of politics, economics, religion, recreation and enjoyment" (243). One interesting thing about associations, as noted by Fadipe (1970) quoted in Adeosun (2017), "is that wherever there is an appreciable community of Yorùbá, either outside Yorùbáland or even only outside their own particular communities, an organisation will spring up complete with officers" (473). The Yorùbá equivalent for association is egbé, which is also used in the sense of "associate".

Fadipe (1970:257) comments that although membership in an egbẹ was not compulsory in traditional Yorùbá society, it was the rule and not the exception to belong to one. A person who had no egbé was not a properly adjusted and socialized being. According to Mcintosh (2010:211), the associations of the colonial period were based upon various sorts of common interests. Though the traditional Yorùbá people sometimes termed themselves 'clubs', 'societies', or 'unions', they combined sociable activities with other functions, 
and they had a basic egbé organizational structure. There are various kinds of associations among the traditional and contemporary Yorùbá which include: occupational guilds, hunters' guild (egbé ọde), league of traders (pàràkòyí), social clubs, secret or initiatory societies, etc. Thus, this paper is concerned with the cultural association among the Nigerian students in tertiary Institutions, known as the Kegite Movement.

\section{Theoretical Framework}

The essay is based on Vygotsky's (1986) socio-cultural theory cited in Adebileje (2012:95-96). The theory, according to Adebileje (2012:95-96), states that,

every function in the child's cultural development appears twice: first, on the social level, and second, on the individual level. That is, first, between people (interpsychological), and second, inside the child (intrapsychological). This implies that the child first relates with people; parents, teachers, siblings and peers to develop culturally before the act is molded and established in him. The primary focus is learning through socialization (95-96).

Adamson and Chance (1998), also, quoted in Adebileje (2012:96) relate the two important aspects in Vygotskian's (1986) approach to social interactions at two levels. They see this approach firstly, as fundamentally cultural and secondly, as a pattern of proximal developmental change in which a phase of adult support precedes a phase of independent infant accomplishment. The adult's reactions and interpretations transform the infant's emerging social behavior into a social act. After many experiences of supported expression, the child gradually masters an action that is qualified with cultural meaning since the act has passed through a development process during which the adult has educated the child in its use. The term 'zone of proximal development' is an essential notion in socio-cultural theory. Vygotsky describes "the zone of proximal development as all of the knowledge and skills that a person cannot yet understand or perform on their own yet but is capable of learning with guidance" (Adebileje, 2012:96). Thus, this paper examines youth's (students) attitude to some aspects of the Yorùbá socio-cultural heritage in the practice of the Kegite movement in Nigerian tertiary institutions.

\section{Origin of the Kegite Movement in Nigeria}

There are two accounts of the origin of the Kegite clubs in Nigeria. The first version which was accounted for by Oduyẹla (1990), who was once a leader (hereinafter referred to as a Chief in the Kegite's parlance) of the Movement in the University of Ibadan branch, revealed that an association named the 
Palmwine Drinkards Club was established in 1962 by a group of students at the University of Ife (now Ọbafẹmi Awolọwọ University) Ile-Ifẹ. According to Oduyela, their main objective was to establish an association which would complement their academic exercise in the University. Their chosen mode of dressing was short sleeve green regalia worn on top of a long sleeve white shirt, accompanied with a small green cap. The first Chief of the Movement, according to Oduyẹla was the late Professor Adeșegun Adeșina.

As further explained by Chief Oduyella, unbeknown to the students of the University of Ibadan that a club known as the Palmwine Drinkards Club existed at the University of Ife, some students had gathered themselves together at the Nnamdi Azikiwe Hall, block B and had formed a club of which the aim was to promote some aspects of the Yorùbá culture. Thus, they named the association the Kegite Club and subsequently held its first initiation ceremony in 1972. Coincidentally, Adéșegun Adeșina, who was the Chief of the Palmwine Drinkards club in the University of Ife, stumbled on them at the initiation ceremony and noticed that there was no significant difference between their activities at Ile-Ifẹ and the one experienced in Ibadan. Hence, he suggested a meeting between the two groups, which was later held in Ile-Ifẹ. Consequently, they both agreed on two major issues which would further strengthen the club. First, they agreed on the pattern of greetings initiated by the Ile-Ife group, which was the use of one-fingered salute as a symbol of unity. Second, they agreed on the mode of dressing adopted by the Ibadan group, which was the wearing of short regalia only. However, the two groups still maintained their different nomenclatures until 1986 when the club was rebranded as the Kegite Club.

The second version of the history of the movement was recorded during the interview held with Bọla Balogun Ojuade, who was a Chief of the club's branch in The Polytechnic Ibadan. According to him, the Kegite movement was founded in 1962 at The Polytechnic Ibadan (formerly known as Technical College). His stance was based on the fact that the School of Arts and Sciences (which was later changed to the University of Ife) was housed by the Technical College before it was relocated to its present site at Ile-Ifẹ. As explained by Ojuade, during the period the two schools were together in Ibadan, some students used to gather together at a spot to drink palm wine, it was this gathering that metamorphosed to a club called The Palmwine Drinkards Club. He also confirmed that the first Chief of the club was the late Professor Adesegun Adeșina whose coronation ceremony took place on the soil of the Polytechnic Ibadan. Chief Ojuade expatiated further that as believed by the Yorùbá, IleIfe was the cradle of the race, thus it was resolved to make the University of Ifẹ (now Obafẹmi Awolowọ University) the World Headquarters of the club. The University of Ibadan, being the premier University in Nigeria, was given 
the status of the National Headquarters, while the Polytechnic Ibadan (where the whole idea was conceived) was accorded the status of the Mother Shrine. In spite of the controversies that trail the origin of the movement, it is established from the two accounts recorded that the movement was established in 1962, and that its first Chief was the late Professor Adeșegun Adeșina. Today, the Kegite Movement has spread throughout the tertiary institutions across Nigeria. It is expedient to emphasize that each branch of the club in an institution is called an Ilya. Ilya in the Kegite's parlance stands for a branch. The nomenclature given to an Ilya has a socio-cultural relevance to the environment in which the institution is situated. For example, Ilya Meleki, which the Olabisi Onabanjo University bears has a link with the traditional chieftaincy title in Ago-Iwoye where the University is located.

\section{Aspects of the Yorùbá Socio-cultural heritage in the practice of the Kegite Movement}

This section probes into some aspects of the Yorùbá socio-cultural heritage as practiced in the Kegite Movement. These aspects are in the formation of associations, selection of an Oba (a king), teaching of morals through music, the use of language (code-talking), and the use of palmwine for entertainment purpose.

\section{Formation of associations}

As I stated elsewhere,

in the Yorùbá traditional society, kinship is the most important relationship. Best friends are very important as well. Also important are clubs that grow out of childhood associations. When a group of young friends starts spending time together, they form a club. They choose a name and invite an older man and woman to serve as advisors. The club continues through to adulthood (Adeosun 2017:474).

They hold monthly meetings with the members serving as hosts in turn. This practice of having associations is replicated by the members of the Kegite movement in Nigerian tertiary institutions. Going by the history of the Movement, it was recorded that the club was formed by a group of students who shared a similar opinion of having an association that would further cement their relationship. It is pertinent, therefore, to state here that there is hardly a Nigerian tertiary institution at which the Kegite Movement is not found. The club serves as a unifying factor among Nigerian youths because of its spread and acceptability. It cuts across ethnic and religious divides. It initially started 
in the Southwestern part of Nigeria, but later spread to other parts of the Country. Members of the Movement relate among themselves cordially, they move from one school to another for various kinds of ceremonies like coronation and initiation. As mentioned earlier, a branch of the club in any tertiary institution is called an Ilya. For instance, in Ahmadu Bello University, Zaria, it is known as Ilya Turban, at the University of Benin it is addressed as Ilya Ovia, at The Polytechnic, Ilaro, Ogun State it is called Ilya Orona, etc.

The Movement is not restricted to schools alone, but extends beyond members' studentship on campuses. After graduation, members have the opportunity of associating with other senior members who have graduated before them. They have a place called Fellosis Convergence or Fellosis Tents. The Fellosis Convergence or Fellosis Tents are established in towns, cities where members gather together. The activities performed there are similar to the ones performed in schools, i.e., singing, dancing, and drinking palmwine. They also have officials who oversee the running of the centers. The Movement transcends beyond the shores of Nigeria. Today, it is found in countries like India, London, Brazil, Liberia and Ghana, etc., founded by the Nigerian Kegites.

\section{Selection of a Chief}

Another way by which the Kegite Movement portrays the Yorùbá socio-cultural heritage is in the selection of its Chief (head of the Club) which is similar to the process by which an Oba is selected and crowned in Yorùbá land. Yorùbá society is structured in a formally monarchical system, institutionalized at the level of the state (oba or monarch), at the level of the dependent units, whether villages (báálẹ) or quarters/town districts (Mọàjí and sectional Chiefs) as well as at that of the lineages or families (báálé, olórí ébí). The Oba is therefore the keystone of the political system which may be characterized as dynastic, namely "stratified in relation to the access to office" (Munoz, 2003:30).

This system of governance is adopted by the Kegite Movement in its modus operandi. The highest principal officer in its structure is the Chief, followed by the Elder, who is closed in rank to the Chief, followed by other officers. The position of a Chief is highly revered as the stool of a king in the Yorùbá society. The selection process of a Kegite's Chief is similar to that of a Yorùbá Oba. The selection process in an Ilya starts with the Elders' Council, headed by the incumbent Elder of the Ilya. The Elders' Council consists of members who are committed final year students. After the meeting, the decision of the Council is usually communicated to all members and non-members in the 
school. Thereafter, a date of coronation of the Chief-elect would be decided and disseminated to all members throughout the country.

On the coronation day, the procedure usually followed in crowning a Yorùbá king is adapted. The Chief-elect would be presented before the audience with his head and face covered with a white cloth while drumming, singing, and dancing are on (which is commonly called gyration in the Kegite's language). Chiefs from other tertiary institutions who are saddled with the responsibility of coronating a new chief would be pouring palmwine on the chief-elect's head and body as he is dancing. Thereafter, he would be told to open one of the two calabashes presented before him. The first calabash contains honey while the second contains pepper. Culturally, these connote both good and bad. On the one hand, if the chief-elect opens a calabash that contains honey, it signifies that his tenure would be good and favorable. On the other hand, if he opens the one that contains pepper, it means that his tenure would be full of crises and disfavor. After this exercise, his face would be unveiled and other rituals would follow. These include, giving him kola nut and alligator pepper to chew, wearing an agbádá (a big regalia) accompanied with a big cap, putting beads on his neck and arms, and finally handing a staff of office, ìrùkẹre (a horsewhip depicting authority) to him. From that moment, he becomes chief of the Ilya. The ceremony is usually climaxed with singing, drumming, and dancing to usher in the new chief.

\section{Promoting Yorùbá Heritage Through music}

Music performs important functions in Yorùbá society, and its functions may differ from one activity to another. Anele (2006) opines that "music lays bare the deepest levels of value and belief, exposes the organization and processes of the culture, and reveals different aspects of the people's behavior" (143). Some of the function's music performs are "promoting a group's feeling of solidarity, providing socially sanctioned ways for individuals to act superior to or to censure other individuals, serving as a vehicle for social protest, converting dull work into play, offering an enjoyable escape from reality, etc." (Anele, 2006:143).

One important thing that endears the Kegite movement in the mind of some people is music. At students' leisure hours, some prefer relaxing where Kegite's members are singing and dancing. This act alone has ignited many students' interest in joining the movement. Although their songs are primarily for entertainment, they are not devoid of teaching morals among students, and condemning social vices in the society. Let us consider some of their songs that teach morals among youths: 
Li'lé: Wúndiá tí ò bálộo

Ėgbè: E lo wộ ko fé

Lílé: 'Boys' ti ò bá láya

Ègbè E lo wáya fé

Lílé: Nitori pé

Ėgbè: Bóyún bá dé o, e yé má mà se

Nítorí íwa i kàyí o, elému òfẹ (Adeosun, 1995:74).

Lead: Ladies that are yet to marry

Chorus: Go and find men to marry

Lead: Boys that are yet to marry

Chorus: Go and find ladies to marry

Lead Why? Because when pregnancy comes, don't attempt abortion.

Chorus: For this wicked act is condemned by the Kegites.

The song condemns in its totality the act of fornication and its attendant consequence of abortion which have become fashionable among students/ youths. According to the song, both fornication and abortion are forbidden by God and also detested by the Kegites. Another song that frowns at evil practices among youths is the one below:

Lílé: Ólárùn opolọ, ò làrù opolo

Ègbè: Eni tó f'ẹlẹmu silè

Tó tún wán șegbé òkükün

O' lárùn opolọ (Adeosun, 1995:75).

Lead: He is mentally sick, he is mentally sick

Chorus: He who forsakes Kegite club

To associate with the secret societies

He is mentally sick

Against the backdrop of insinuations from some quarters that the Kegite Movement is, perhaps, a secret society, this song is instructive. The song likens whoever associates with any form of cultism to a lunatic, thus, it warns the students/youths against such act. From the song, therefore, the Kegite club is presented as an open association that accommodates only responsible and disciplined people. Owing to the fact that the Kegite Movement is not apathetic to the happenings in its environments and the country at large, most of its songs are used as protest to condemn evils being perpetrated by the government functionaries. The following song will suffice: 
Lilé: Èwólewóo

Èwólewó?

Ègbè: Èwólewó o

Exólewó?

Lilléàti gbígbè: Oyinbó lọ tán o, Bàléwà dé

Bàléwa lo tán o, Irósi dé

Irósi lo tán o, Gơwónù dé

Gơợnu lo tán o, Mưritàlá.

Muritàlálo tán o, ộbásanjọ.

ờbásanjọ lo tán o, Shàgári dé.

Shàgári lọ tán o, Buhári dé.

Buhári lo tán o, Bàbángi dá.

Bảbángi dálo tán o, Sơnẹkàn dé.

Sonẹkàn lo tán o, Ałbáchà dé.

T'A'báchà bálọ tán o, èwólèwo? (Adeosun, 1995: 91-92).

Lead: What next? What next?

Chorus: What next? What next?

Lead \& Chorus: Colonial masters left, Balewa took over

When Bàléwà left, İrósì came

When İrósì left, Gowọn came.

When Gowọn left, Mưrítàla came.

When Mưrítàlá left, ọ̀básanjọ́ came.

When ờbásanjọ́ left, Shàgári came.

When Shàgári left, Bùári came.

When Bủari left, Bàbángi dá came.

When Bảbángì dá left, Șonệkàn came.

When Șonẹ́kàn left, Ảbáchà came.

After Àbáchà, what next?'

This is a politically charged song, composed to satirize the failure of the Nigerian successive leaders since the nation's political independence of 1960. The first four lines of the song are couched with a rhetorical question "What next?" Going by the sequence of the song, the country was in the state of hopelessness. The song has an elastic refrain in its structure; it accommodates any personality in power for as long as her economy remains in comatose as it was as at the time of writing this paper.

\section{The Use of Language (Code-talking)}

The Kegite Movement promotes the Yorùbá socio-cultural heritage through the use of language (code-talking). The importance of language in any human 
society cannot be over emphasized. Language is vital to communication, without language in any form; there can be no communication of whatever nature. Adeosun (2010:6) notes that communication generally is any information sharing activity. It is an individual and collective activity embracing all transmission and sharing of ideas, fact and data. Whichever way one looks at it, communication is the means or the system of exchange of ideas, attitudes, opinions, feelings, information and so on within a person (intrapersonal), and among persons (interpersonal), and collectivities (mass). Adeosun (2010) notes further that in expressing or exchanging of thoughts/concepts therefore, "there is a signaling system which utilizes vocal sounds used by a group of people for the purpose of communication and social co-operation. Whatever mode of communication employed, what is most important is for the listener to be able to understand and interpret the message sent by the speaker" (6).

From the foregoing, it is imperative to mention that the Kegite members have a unique language employed to communicate among themselves. This unique language is what is described as code-talking. Code-talking is quite cryptic and so it needs special knowledge to be able to decipher it. Among the signs employed in Yorùbá language is ẹnà which Iṣọla (1982: 43) describes as code talking. Code-talking is a symbol distorted to create a secret language that is freely used among a set of people. Code-talking is not hidden to its users for it is used to communicate effectively. In other words, it is said to be hidden to a non-user because he or she lacks the understanding of its guiding rules.

Among the members of the Kegite Movement, they use code to communicate effectively on any discourse. For example, one of the prominent senior members of the club posted a message on his page of the Facebook on April $3^{\text {rd }}$ 2017. This message was sent to the members of the club announcing the sudden death and burial of one of the Life Senior Fellows of the club, Dr. Kehinde Obasan which would come up on April $4^{\text {th }}$, 2017. The message reads:

Let all alhajis and alhajas by way of ijimujis in the whole galaxy telewire bush rats that tomorrow is d Day D for an LSF who has decided out of his own indecisive decision to climb the iroko tree and interact with Lsf Jesus. May we all walk. All Melekites celebrate your elevation to baba Eledumare. To God I have vibrated.

This information was disseminated and effectively decoded by the members concerned. Immediately, members were sending their condolences to commiserate with the family of the deceased and the club. Thus, the burial witnessed a mammoth crowd of members and other sympathizers. 


\section{Using Palmwine for Entertainment Purpose}

The Yorùbá traditional entertainment includes rituals, dancing, music making, and other ceremonies like marriage, naming, housewarming, burial, etc. During these activities, food and drinks, including palm wine, are supplied in large quantity. Even after their day's strenuous work, they recreate by playing a game called ayò olopon, a type of game played on a board with two rows of indentations or wells that are filled with small seeds. While this game is on, the players and the audience are usually relaxed with palmwine. This practice is thus replicated by the Kegite Movement in Nigerian tertiary institutions where members come together to relax after a day's academic rigor. They are of the opinion that palmwine is a natural gift by God which does not pass through any processing before its consumption. Apart from its entertainment value, it also serves as a source of employment generation for the palmwine tappers, as well as the sellers of palmwine in various schools Kegite Movement is found.

\section{Conclusion}

This essay has brought to the fore some aspects of the Yorùbá socio-cultural heritage in the practice of the Kegite Movement in Nigerian tertiary institutions using a socio-cultural theory. In order to achieve this, a review of relevant literature was carried out where efforts were made to discuss some concepts like heritage, culture, and some basic elements of culture. Also, the importance of associations among the Yorùbá was discussed. In the analysis, five aspects of the Yorùbá socio-cultural heritage in the practice of the Kegite Movement were identified and discussed. These are: formation of associations, selection of an Oba, teaching of morals through music, use of language (codetalking), and the use of palmwine for entertainment purpose.

\section{Bibliography}

Adebileje, A. 2012. "Socio-cultural and attitudinal study of selected Yorùbá taboos in South West Nigeria." Studies in literature and language 4(1): 94-100.

Adeosun, H. O. 1995. “İtúpalẹ orin ẹgbẹ ẹlẹ́mu ti ẹka Yunifásítì İpínlẹ Ògun, Àgọ́-İwoye’”. B. A. Long essay, Department of Nigerian Languages and Literatures, Ogun State University, Ago-Iwoye.

Adeosun, H.O. 2010. "Indigenous languages and mass communication media in Nigeria: The case of Yoruba". Centrepoint: A journal of intellectual, scientific and cultural interest 13(1): 1-13. 
Adeosun, H.O. 2017. "Associations: Cultural, cooperative, and religious". In Falola T, Akinyemi A. (eds). Culture and Customs of the Yorùbá. Austin, Texas: Pan-African University Press. pp. 473-480.

Anele, K. 2006. "Social change and Nigerian heritage". In: Anikpo M.O.C., Atemie J.D. (eds), Nigerian Socio-cultural Heritage, Port Harcourt: Amethyst \& colleagues. pp. 139-151.

Atemie, J.D, Girigiri B.K. 2006. "The concept of culture". In: Anikpo M.O.C., Atemie J.D. (eds), Nigerian Socio-cultural Heritage, Port Harcourt: Amethyst \& colleagues. pp.1-13.

Fadipe NA. 1970. The sociology of the Yorùbá. Ibadan: University press.

Folorunso, O, Folorunso F.J. 2012. "Preservation and conservation of Yorùbá cultural artifacts: The place of Nigerian libraries and archives." African Research Review 6(1): 256-262.

Girigiri, B.K. 2006. The Nigerian heritage: Historical and socio-cultural conceptualization. In: Anikpo M.O.C, Atemie J.D (eds), Nigerian Socio-cultural Heritage, Port Harcourt: Amethyst \& colleagues. pp.14-29

Isola, A. 1982. "Enà' code-talking in Yorùbá." Journal of West African languages 21(1):43-51.

Mcintosh, M.K. 2010. Yoruba Women, Work, and Social Change. Ibadan: Bookcraft.

Munoz, L.J. 2003. A living tradition. Studies on Yorùbá civilisation. Ibadan: Bookcraft.

Oduyẹla, S.O.O. 1990. "The socio-political and religious significance of the kegite movement on African belief system in Nigeria”. B. A. Long essay, Department of Religious Studies, University of Ibadan, Ibadan.

Peil, M. 1977. Consensus and Conflict in African Societies: An introduction to Sociology. London: Longman.

Sanderson, S.K. 1988. Macrosociology: An Introduction to Human Societies. New York: Harper and Row.

Thomas, W.L, Anderson R.J. 1977. Sociology. The Study of Human Relationships. New York: Harcourt Brace Jovanovich.

Vygotsky, L. 1986. Thought and Language. Cambridge, MA: The MIT press. 